ISSN:

Print - 2277-078X

Online - $2315-747 \mathrm{X}$

(c) UNAAB 2017

Joumal of

H umanities, Social

Sciences and Creative Arts

\title{
PERCEIVED EFFECT OF EMPLOYEES PARTICIPATION IN ORGANIZATIONAL DECISION MAKING ON JOB SATISFACTION IN NATIONAL INSTITUTE FOR HORTICULTURAL RESEARCH AND TRAINING, OYO STATE NIGERIA
}

\author{
1R. A., OYEYIN KA, 20.A., ADEKUNMI, 1S.0., AYANSINA, 2A.0 .AWOYEMI
}

1D epartment of Agricultural Administration, Federal University of Agriculture, Abeokuta, Nigeria.

2D epartment of Agricultural Economics \& Extension Services,

Faculty of Agricultural Sciences, Ekiti State University, Ado - Ekiti, Nigeria

*Corresponding Author: akinoye2009@gmail.com Tel: +2348033798232

\begin{abstract}
The study was conducted to investigate the perceived effect of employees' participation in organisational decision making on the job satisfaction in National Institute for Horticultural Research and Training, Oyo State, Nigeria. Structured questionnaire were used to collect data from 82 employees using simple random sampling technique. Data were analysed using both descriptive and inferential statistics. The results showed that majority of the employees (51.9\%) were female and belong to the age range of 30-40years, with a mean age of 38.3years. Thisis a reflection of gender imbalance of the employees in the organisation. Furthermore $49.1 \%$ of the respondents' were married, while $86.4 \%$ of them obtained tertiary education. Moreover the monthly average salary of the respondents was about $\mathrm{N} 100,000.00$. The aggregate mean score for level of participation in decision making was 36.21 , while
\end{abstract} the grand mean was 4.02. Satisfaction with co-workers relationship with mean value of $\left({ }^{\bar{x}}=3.71\right)$, unity of command amongst the employees with mean value of $\left({ }^{\bar{x}}=3.63\right)$, and satisfaction of the structure in the organisation had greater effect on the employees level of job satisfaction as indicated in the perception of employees rating means scores. Result also shows that, lack of motivation (62.2\%), domination by some group (76.8\%), and poor communication (71.9\%) were the most severe constraints responsible for poor participation in decision making in the organisation. Chi square and Pearson product moment correlation analysis shows that age $\left(x^{2}=0.257, p<0.05\right)$, educational level $\left(x^{2}=0.258, p<0.05\right)$, years of experience $(r=0.239, p<0.05)$ and monthly salary $(r=0.247, p<0.05)$ had significant association with participation in organizational decision making. Also the result of Pearson Product Moment Correlation reveals that there is significant relationship between the respondents' participation in decision making and job satisfaction $(r=0.652, p<0.05)$. The study concludes that the effect of employees' participation in organisation decision making on job satisfaction was rated above average. It is therefore recommended that employees' motivation should be adhere to in the organization by involvement of employees' and participation in decision making.

keywords: Effect, Participation, Organisational, Decision Making, Job Satisfaction. 


\section{INTRODUCTION}

In today's turbulent environment and intense competition, firms are forced to seek ways to be more flexible, adaptive and competitive as they are faced with competitive pressures and rapidly changing markets. Success depends on involving the entire workforce on capacity to generate new ideas and ways of working to outsmart the competitors. Employees must be involved if they are to understand the need for creativity and be committed to changing their behaviours in work, and adopt a new and improved ways of doing things.

Employee involvement is one important aspect of organizational life to achieved increased organizational effectiveness and positive employee perceptions. Employee participation in decision making is one of the many current forms of employee involvement in the workplace decision making. Managers are encouraged to allow a high degree of employee participation and autonomy, which are intended to increase workforce commitment and to humanize the workplace with the intention of improving work performance and good citizenship behaviour (Brenda and Verena, 2004).

Participation in decision making is not new and its research can be traced back to several decades. Approaches such as Participation decision making gained new prominence in 1980s because businesses faced new competitive challenges that demanded higher levels of performance (Poole et al., 2001).

Employee Participation is generally defined as a process in which influence is shared among individuals who are otherwise hierarchically unequal (Wagner, 2004, Locke and Schweiger, 2009). Participatory manage- ment practice balances the involvement of managers and their subordinates in information processing, decision making and problem solving endeavours, (Wager, 2012). Coch and French (2009) are considered to be the pioneers in studying employee participation in the workplace. They developed the productivity and efficiency rationale, assuming that there is a direct link between employeese involvement in decision-making and work outcomes such as the increase of job satisfaction and productivity. Participation in decision-making can satisfy employeese self-actualization needs and, by doing so, increase employeese motivation and job performance (Allen and Seaman, 2007).

The individual factors that influence the existence of participation in decision making is the main focus of the study. Such a study is useful in determining appropriate measures to be taken to increase or decrease certain factors that may increase or reduce the likelihood of participation in decision making. Employee participation is considered as a combination of different tools designed to increase employee input of various degrees in managerial decision making like organizational commitment, reduction of employee intention to turnover and absenteeism, increase in productivity and motivation. There has been significant attention from researchers that focus on the manner in which structure affects employee attitudes. (Singh and Sharan,2009),in their study, stated that in current dynamic working environment and severe competition, organizations are required to adopt techniques which are flexible, adaptive and competitive due to the competitive pressures and rapidly changing market conditions. More over organizations are realizing that their employees are the most important asset and organizations future depends on more involvement of em- 
ployees in generating new ideas. The involvement of employees can help in many ways to the organizations looking for creativity, changes in behaviours at work, and in workplace decision making. In many cases, managers are encouraged to allow a high degree of employee participation and autonomy to increase workforce commitment. Employee participation represents the combination of task-related practices, which aim to maximize employee sense of involvement in their work, and human resource management practices that aim to maximize employees' commitment to the wider organization. Varieties of employee involvement practices are included to support the task-related practices. These supporting practices include: training, to improve employees problem-solving and communication skills; financial participation schemes, to enhance the link between effort and reward: and an emphasis on job security and internal promotion, to engender employees' commitment to organizational success. So far, the relationship between the employee participation and organizational commitment is not yet fully understood, partially because researchers focus their study on participation or commitment in relation to performance, instead of the direct link between participation and commitment, (Wager,2012).

Job satisfaction is basically described as the feelings that an employee has about his/ her job. Job satisfaction is an interesting topic to both people who work in an organizations and people who study them. Job satisfaction can be formally defined as the degree to which individuals feel positively and/ or negatively about their jobs, it is also the degree of fit between the features of a job and employees expectation, (Tutuncu and Kozak, 2007).
Employees experience a feeling of accomplishment if their desired expectations are met, that will ultimately determine the degree of satisfaction. In other words, job satisfaction befalls when a job meets values, expectations and standards of an individual and will stimulate their commitment and performance (Y ousef, 2000).

\section{PROBLEM STATEMENT}

There has been a lot of controversy pertaining to an employee participation in management decision making. Some writers argued that employees should contribute in making decision more especially where it affects them or their jobs. It is expected that such participation will serve as training and testing ground for future members of upper management and these issue is really causing set back in organization growth. In other to unravel this assertion this study was conducted to assess the perceived effect of employee participation in organization decision making on job satisfaction in National Horticultural Research Institute (NIHORT).

\section{OBJECTIVES OF THE STUDY:}

The specific objectives of the study are to:

1. ascertain the socio-economic economic characteristics of the employees'.

2. determine the level of employees' participation in decision making in the organization.

3. examine the perceived effect of employees' participation in the organizational decision making on their job satisfaction.

4. identify the causes of poor participation in decision making in the organization. 
$\mathbf{H}$ ypotheses of the study: Based on the in the derived savannah Zone of western objectives of the study the following hypotheses were tested in the null form.

Ho: there is no significant relationship between respondents' socio-economic characteristics and their participation in organizational decision making.

Ho2: there is no significant relationship between employees' participation and their job satisfaction.

\section{METHODOLOGY:}

This study was carried out in National Horticultural Research Institute (NIHORT), Oyo state, Nigeria, which started as The National Fruit and Vegetable Research and Development Centre (NFVRDC) with the assistance of UNDP/FAO project5 NIR/ 72/ 007, by the Federal Government Agricultural Research Institutes Establishment Decree Order No. 35 of June 1975, which later metamorphosed into the $\mathrm{Na}$ tional Horticultural Research Institute (NIHORT).

The institute is under the coordination of the Agricultural Research Council of Nigeria (ARCN). In 1980, the Science and Technology Bill of 1980 transferred the institute to the Ministry of Science and Technology. However, since1992, it has been under the Federal Ministry of Agricultural and Rural D evelopment.

The institute has 1,671hectares of land with the headquarters on 350 hectares of land at Jericho reservations Area Idi-ishin, Ibadan Nigeria. The institute also has two substations: one located at Mbato-Okigwe Imo state on an 810-hectare land in the mid forest zone of South Eastern Nigeria: and the other at Bagauda, Kano, and Kano State on 310hectares in the semi-arid zone of Nigeria. There are two experimental stations, one situated on 75 hectares of land at Riyom near Jos, Plateau State in mid altitude and other at Dadinkowa, Gombe, Gombe State on 126 hectares of land in the Guinea Savannah Zone of the country.

The population of the study includes all employees of NIHORT in Ibadan, Oyo State, Nigeria. The total number of staff is 824 both junior and senior staff. Simple random sampling technique was used to select 82 respondents from the population, which represent $10 \%$ of the population. This gives a sample size of 82. Primary data was collected through the use of questionnaires while secondary data was obtained from journals, internet and other publications related to the study. Employees were chosen from various departments of the organization, which include researcher and non-researcher. Both descriptive and inferential statistics was used to carry out the analysis of the data collected. Descriptive statistics include frequency counts, percentages, means and standard deviation. Inferential statistics such as Chi Square, Pearson Product Moment Correlation (PPMC) was used to test the proposed hypotheses for the study. 
PERCEIVED EFFECT OF EMPLOYEES PARTICIPATION IN...

Table O ne: Show the Sample of Respondents for the Study

\begin{tabular}{llll} 
S/ N & Department & $\begin{array}{l}\text { Employee } \\
\text { Population }\end{array}$ & $\begin{array}{l}\text { 10\% of Selected } \\
\text { Employees }\end{array}$ \\
\hline 1 & $\begin{array}{l}\text { Agricultural research system } \\
\text { and extension }\end{array}$ & 340 & 34 \\
\hline 2 & Human resource development & 184 & 18 \\
3 & Financial / Accounting & 125 & 12 \\
4 & Agricultural Administration & 89 & 9 \\
5 & Works and planning & 43 & 4 \\
6 & Citrus department & 43 & 4 \\
Total & & 824 & 82 \\
\hline
\end{tabular}

\section{RESULTS AND DISCUSSION Socio-economic characteristics of $\mathrm{Re}$ - spondents:}

The result in table 1 showed that majority $(40.7 \%)$ of the employees belong to the age range of 30-40years, while a few (2.5\%) belong to the age range of above 50 years. The mean age is 38.3 which is in line with the findings of (Adekunmi et al, 2017. The implication of this finding is that most of the workers in the organisation are in their active age and this would give them the opportunity to perform optimally their duties. Also Table 1 showed that (51.9\%) of the respondents were female, while (48.1\%) were male. This reflects gender imbalance of the employees in the organisation. Furthermore $49.1 \%$ of the respondents' were married, $32.1 \%$ of them were single, $12.2 \%$ were divorced and $6.6 \%$ were widowed. This implies that an average employees in the organization were married and responsible citizen, which influence their rate of participation in the organizational decision making. Moreover, $86.4 \%$ of the employees obtained tertiary education, while $13.6 \%$ have secondary education. This indicates that tertiary educations were the dominant qualification in the organization. This support the findings of Bolarinwa, et al,2014) who posited that majority of the employees in an agricultural organisation had tertiary education. The results in Table 1 also revealed that majority of the employees $84.0 \%$ were Christians, while a few $16.0 \%$ were Muslims. It was observed that, $50.6 \%$ of the employees had 11-20 years working experience, while a few $7.4 \%$ had above 20 years' experience. The result of the analysis of the monthly salary of the respondents in Table 1 shows that $44.4 \%$ of the respondents earned above N100, 000, while a few $8.6 \%$ earned about N30, 000.The mean monthly income of the respondents is N93, 888.89.This implies that the monthly salary of respondents is relatively high to motivate them in their job performance. 
R. A., OYEYINKA, O.A., ADEKUNMI, S.O., AYANSINA, A.O.AWOYEMI

Table 1. Frequency distribution showing the socio-economic characteristics of the respondents $(\mathrm{n}=\mathbf{8 2})$

\begin{tabular}{|c|c|c|c|c|}
\hline \multirow{2}{*}{$\begin{array}{l}\text { Variables } \\
\text { Age group (years) }\end{array}$} & Frequencies & Percentages (\%) & Mean & Std. D ev. \\
\hline & & & & \\
\hline$\leq 30$ & 18 & 22.2 & & \\
\hline $30-40$ & 33 & 40.7 & 38.25 & 7.058 \\
\hline $40-50$ & 28 & 34.6 & & \\
\hline$\geq 50$ & 3 & 2.5 & & \\
\hline Sex & & & & \\
\hline Male & 39 & 48.1 & & \\
\hline $\begin{array}{l}\text { Female } \\
\text { Marital Status }\end{array}$ & 43 & 51.9 & & \\
\hline Single & 26 & 32.1 & & \\
\hline Married & 41 & 49.1 & & \\
\hline Divorced & 10 & 12.2 & & \\
\hline Widowed & 5 & 6.6 & & \\
\hline Education & & & & \\
\hline Secondary & 12 & 13.6 & & \\
\hline Tertiary & 70 & 86.4 & & \\
\hline Religion & & & & \\
\hline Christianity & 68 & 84 & & \\
\hline Islam & 14 & 16 & & \\
\hline Years of experience & & & & \\
\hline$\leq 10$ & 34 & 42 & 12.16 & 5.293 \\
\hline $\begin{array}{l}11-20 \\
>20\end{array}$ & $\begin{array}{l}42 \\
6\end{array}$ & $\begin{array}{l}50.6 \\
74\end{array}$ & & \\
\hline Monthly salary & & & & \\
\hline$\leq 30,000$ & 7 & 8.6 & & \\
\hline $31,000-50,000$ & 12 & 14.8 & 93888.89 & 37458.31 \\
\hline $51,000-100,000$ & 26 & 32.1 & & \\
\hline$\geq 100,000$ & 37 & 44.4 & & \\
\hline
\end{tabular}

Source: Field survey, 2015

Level of Employees' Participation in Decision Making

Results in Table 2 summarised the survey that indicate the respondents level of participation in decision making in the organisation. The aggregate mean score for level of participation in decision making was 36.21, while the mean for the grand mean was 4.02.The mean of the grand mean indicated the overall level of employees' participation in decision making. Workers influence on their job, unity of command and satisfy with promotion opportunity in the job as indicated in the level of employees rating means scores of 4.23, 4.12, and 4.09 respectively as shown in Table 2 had grater mean scores. Other levels of participation in decision making recorded medium perception score, 
while satisfy with pay on the job recorded the lowest means perception score of 3.75.The implication of this finding is that the organisation did not involve the employees on matter relating to increment in salary of staff, however level of participation in decision making of the employees' was higher than average of five points on the rating scale.

Table 2: Level of Employees Participation in Decision Making.

\begin{tabular}{lll}
\hline Statement & Mean & Standard D eviation \\
\hline How much influence do you have on your job & 4.23 & 0.886 \\
Satisfy with the unity of command & 4.12 & 0.914 \\
To what extent are you able to do your job & 4.09 & 1.002 \\
Satisfy with promotion opportunity in the job & 4.09 & 0.938 \\
Recognition of staff by management & 4.05 & 0.890 \\
Satisfaction with organizational policies & 4.04 & 0.865 \\
Satisfy with conditions of my job & 3.93 & 0.978 \\
Satisfy with security my job provides me & 3.91 & 1.034 \\
Satisfy with pay received for my job & 3.75 & 1.119 \\
G rand Mean Score for level of participation & 4.02 & \\
\hline
\end{tabular}

Source: Field survey, 2015.Grand mean $=4.02$

\section{Level of Job satisfaction of E mployees in the 0 rganization.}

Table 3 shows the level of job satisfaction of the employees' in the organisation. Satisfaction with co-workers relationship with mean value of $\left({ }^{\bar{x}}=3.71\right)$, unity of command amongst the employees with mean value of $\left({ }^{\bar{x}}=3.63\right)$, and satisfaction of the structure in the organisation had greater effect on the employees level of job satisfaction as indicated in the perception of employees rating means scores in Table 3.However, security of staff with a mean value of $\left({ }^{\bar{x}}=3.22\right)$, and benefits/ incentives derived in the organisation by employees ( $\bar{x}$ $=3.14$ ) had less effect on the employees level of job satisfaction. The aggregate mean score for level of job satisfaction by the employees was 30.75 , while the mean for the grand mean was 3.41.The mean of the grand mean indicated the overall effect of participation in decision making on employees job satisfaction. The findings imply that the effect of participation in decision making on employees job satisfaction was higher than the average of five points on the rating scale. 
R. A., OY EY INKA, O.A., ADEKUNMI, S.O ., AYANSINA, A.O .AWOYEMI

Table 3: Level of Job Satisfaction of Employee in the Organization

\begin{tabular}{lll}
\hline Statement & Mean & Standard D eviation \\
\hline Satisfaction with co-workers relationship & 3.71 & 0.879 \\
Satisfaction with the unity of command & 3.63 & 1.146 \\
Satisfaction with the organizational structure & 3.62 & 1.136 \\
Promotion opportunity is satisfying & 3.49 & 0.950 \\
Recognition of staff by management & 3.42 & 0.947 \\
Satisfaction with organizational policies & 3.28 & 1.115 \\
Satisfaction with job conditions & 3.22 & 1.154 \\
Security of staff & 3.22 & 1.169 \\
Satisfaction with the benefits/ incentives & 3.14 & \\
Grand Mean Score for level of job Satisfaction & 3.41 & \\
\hline
\end{tabular}

Source: Field survey, 2015.G rand mean $=3.41$

Constraints of Participation in Decision Making in the Organization.

Table 4 shows the major constraints of participation in decision making in the organisation. The table shows that, lack of motivation $(62.2 \%)$, domination by some group $(76.8 \%)$, centralised organisation structure $(52.4 \%)$, managers differ in decision making $(75.6 \%)$, and poor communication $(71.9 \%)$ were the most severe constraints responsible for poor participation in decision making in the organisation. Furthermore, lack of education (75.6\%), competition among employees (76.8\%) and organisation culture $(75.6 \%)$ were some of the constraints that were not severe for participation in decision making in the organisation.

\section{$H$ ypotheses Testing:}

There is no significant relationship between respondents' socio-economic characteristics and their participation in organizational decision making. This hypothesis was tested using chi-square and Pearson product moment correlation in the null form at $p<0.05$ level of error. Result of the chi-square in Table $5 A \& B$ showed sex $\left(\chi^{2}=0.330, p>0.05\right)$, age $\left(\chi^{2}=0.257, p>0.05\right)$, and religion $\left(\chi^{2}=0.240\right.$, $p>0.05)$, had no significant association with employees participation in decision making. However age $\quad\left(\chi^{2}=0.257, \quad p<\right.$ $0.05)$,educational level $\left(\chi^{2}=0.258, p<0.05\right)$, years of working experience $(r=0.239, p<$ $0.05)$ and monthly salary $(r=0.247, p<0.05)$ had significant association with participation in organizational decision making. This implies that age, education level, years of working experience and monthly income of the employees werekey factors of decision making process in the organization. 
PERCEIVED EFFECT OF EMPLOYEES PARTICIPATION IN...

\section{Table 4: Constraints on Level of Participation in Decision Making in the Organization}

\begin{tabular}{lllllll}
\hline S/ N & Statements & VS & S & NS & $\overline{\boldsymbol{x}}$ & S.D \\
\hline 1 & $\begin{array}{l}\text { Lack of motivation to participate in deci- } \\
\text { sion. }\end{array}$ & $18(21.9)$ & $51(62.2)$ & $13(15.9)$ & 1.76 & 0.98 \\
2 & $\begin{array}{l}\text { D omination by a person may cause poor } \\
\text { participation in decision making. }\end{array}$ & $63(76.8)$ & $13(15.9)$ & $6(7.3)$ & 1.72 & 3.64 \\
3 & $\begin{array}{l}\text { Centralized organizational structure } \\
4\end{array}$ & $11(13.9)$ & $43(52.4)$ & $28(34.1)$ & 1.64 & 0.72 \\
& $\begin{array}{l}\text { Managers as individuals differ in their deci- } \\
\text { sion making. }\end{array}$ & $62(75.6)$ & $8(9.8)$ & $12(14.6)$ & 1.41 & 0.75 \\
& $\begin{array}{l}\text { The downward communication in the or- } \\
\text { ganization causes poor participation in deci- }\end{array}$ & $7(8.5)$ & $59(71.9)$ & $16(19.5)$ & 1.38 & 0.65 \\
6 & $\begin{array}{l}\text { sion making. } \\
\text { Lack of educational qualification. }\end{array}$ & $5(6.8)$ & $15(19.3)$ & $62(75.6)$ & 1.32 & 0.59 \\
7 & $\begin{array}{l}\text { Management does not want to motivate all } \\
\text { employees. }\end{array}$ & $10(12.2)$ & $4(4.9)$ & $68(82.9)$ & 1.32 & 0.70 \\
8 & $\begin{array}{l}\text { Competition among employees causes poor } \\
\text { participation in decision making. }\end{array}$ & $10(12.2)$ & $9(10.9)$ & $63(76.8)$ & 1.30 & 0.63 \\
9 & $\begin{array}{l}\text { The tradition of the organization causes } \\
\text { poor participation in decision making. }\end{array}$ & $9(10.9)$ & $11(13.4)$ & $62(75.6)$ & 1.29 & 0.67 \\
10 & $\begin{array}{l}\text { Workers who take part in decision making } \\
\text { are too many. }\end{array}$ & $6(7.3)$ & $13(15.9)$ & $63(76.8)$ & 1.28 & 0.60 \\
& $\begin{array}{l}\text { Grand Mean Score for level of poor partici- } \\
\text { pation }\end{array}$ & & & & 1.44 & \\
\hline
\end{tabular}

Source: Field survey, 2015.Grand mean $=1.44$

NB: Figures in the parenthesis are in percentages. VS $=$ Very Severe, $\mathrm{S}=$ Severe, NS $=$ Not Severe ${ }^{\bar{x}}=$ Mean, S.D $=$ Standard D eviation.

Table 5A: Relationship between respondents' socio-economic characteristics and their participation in organizational decision making.

\begin{tabular}{lllll}
\hline Variables & $x^{2}$ & Df & P- value & Decision \\
\hline Sex & 0.330 & 1 & 0.855 & NS \\
Age & 0.257 & 3 & 0.026 & $\mathrm{~S}$ \\
Religion & 1.240 & 1 & 0.265 & $\mathrm{NS}$ \\
Educational level & 0.258 & 1 & 0.029 & $\mathrm{~S}$ \\
\hline
\end{tabular}

Source: Field survey, 2015.

J. Hum. Soc. Sci. Crtv. Arts 2017, 12: 1- 12 
Table 5B: correlation analysis between respondents' socio-economic characteristics and participation in organisational decision making.

\begin{tabular}{lclc}
\hline Variable & Correlation coefficient $(\mathbf{r})$ & $\mathbf{p}$-value & Decision \\
\hline Years of experience & -0.239 & 0.027 & $\mathrm{~S}$ \\
Monthly salary & -0.247 & 0.028 & $\mathrm{~S}$ \\
\hline
\end{tabular}

Source: Field Survey, 2015

\section{H ypothesis T wo:}

There is significant relationship between respondents' participation and their job satisfaction. This hypothesis was tested using Pearson Product Moment Correlation in the null form at $p<0.05$ level of error. The result in Table 6 reveals that there is significant relationship between the respondents' participation in decision making and job satisfaction $(r=0.652, p<0.05)$. This implies that participation in decision making is signifi- cantly related with employees' job satisfaction. That is involvement of the employees

on key issues that affect their welfare on the job influence their behaviour, overall performance and effectiveness in the organisation. This is corroborated by the findings of (Carriere \& Bourque, 2009), who posited administratively, that job satisfaction has an important influence on employee behaviour and performance.

Table 6: Hypothesis of Relationship Between Respondents' Participation and their Job Satisfaction.

\begin{tabular}{lllll}
\hline Variables & R & N & P - value & Decision \\
\hline Participation and Job satisfaction & 0.652 & 82 & 0.001 & $\mathrm{~S}$ \\
\hline
\end{tabular}

Source: Field survey, 2015 


\section{CONCLUSION}

The study concludes that majority of the employees' with a greater proportion of them still in their economically active age require for civil servant in government employment. Also majority of the respondents obtained tertiary education with a mean monthly income of about (N100, 000.00). The study also show that workers influence on their job, unity of command and satisfaction with promotion opportunity on the job had greater effect on their participation in decision making,while satisfy with pay on the job recorded the lowest means perception score.Security of staff, and benefits/ incentives derived in the organisation by employees had less effect on the employees' level of job satisfaction. However, the effect of employees' participation in organisation decision making on job satisfaction was rated above average.

\section{RECOMMENDATIONS}

Based on the findings of the study, the following recommendations were made.

1. Employees' motivation should be adhere to in the organization by involving them on importance matters in decision making.

2. Management should try to decentralize the organizational structure as this would provide the employees with the basic and essential knowledge of participation in decision making.

3. Participation in decision making should be extended to all employees irrespective of their rank, years of experience and field of operation as each employee will contribute its own quota to the growth of the organization.

4. A good communication level and relationship should be encouraged and maintained between the employees' and their superiors in the organization.
5. Security of staff should be made a priority in the organization to encourage the outcome and efficient participation in decision making.

6. Incentives and benefits of employees' should be paid as at when due and the frequency of pay rise should not be delayed.

\section{REFERENCES}

Adekunmi, O.A., Oyeyinka, R.A., Awoyemi, O.A., Ayansina, S.0. 2017: Comparative Economic Analysis of Rainy and D ry Season Maize Production Among Farmers in Ekiti State, Nigeria. Eurqpen Jarrnel of Business and Managemet, 9(14) Pp 25- 26

Allen, E., Seaman, C., 2007.Likert Scale and Data Analysis. Quality Progress 2007, Pp 64- 65

Brenda, S.L., Verena, M. 2004. articipation in Decision Making. A matter of Context. Leadaship and Organisation Dedeqment Jarrnal.25 7/ 8, Pp 646- 662

Bolarinwa, K.K., Oyeyinka, R.A., Fapojuwo, O.E., Adeogun, S.0. 2014. Employees Perception of Effect of Organisation Communication on Job Performance in Ogun State Agricultural Development Programme, NiggiaMoor Jarmal of Agialtural Reserch 15 p72.

Camiere, J., \&Bourque, C.2009.The Effect of Organisational Communication on Job Satisfaction and Organisational Commitment in a Land Ambulance Service and the Mediating Role of Communication Satisfaction. Career Dedepment Intemational, 14(1), Pp2949

Coch \& French. 2009: Article in Human 
Relations: A Critique \& Interpretation. International Ja umal of Engineeing34 (7) 555-566

Locke, E.A., Schweiger, D.M. 2009: Participation in Decision-making: O ne More Look. Research in Organizational Behaviar.1: 265-339.

Poole, Lansbury, Wailes.2001:"A Comparative Analysis of Developments in Industrial D emocracy: A Comparative Analysis", Industrial Rdations vol. 40, No. 3.

Singh, G., Sharan, K.2009.A Study on Employee Participation in Decision Making", Unitar E-Jaumal, Vol: 5, No: 1, Pp: 20 38.
Wager, J.A. 2012.Effects of participation on performance and satisfaction: Additional meta-analytic evidence. In: Psychdogical Reparts, 90, Pp 719-725.

Wagner, A.J. 2004. "Participation's effects on performance and satisfaction: A reconsideration of research evidence, "A Acadamy of Management Review", vol.19, Pp. 312-30.

Yousef, D. A. 2000. "O rganizational commitment: a mediator of the relationships of leadership behaviour with job satisfaction and performance in a non-western country", Jaumal of Managgial Psychdogy", vol.15, no. 1, pp. 6-24.

(Manuscipt received: 15hAugst, 2016; accepted 19thMarh, 2018). 